\title{
Long-term study of the life cycle of the freshwater snail Heleobia parchappii (Mollusca: Cochliopidae) in a lentic environment in Argentina
}

\author{
Matías J. Merlo*, Manuela Parietti and Jorge A. Etchegoin \\ Laboratorio de Parasitología, Facultad de Ciencias Exactas y Naturales, Universidad Nacional de Mar del Plata, \\ Funes 3350, 7600 Mar del Plata, Argentina. \\ * Corresponding author: mjmerlo@mdp.edu.ar
}

Received: 20/02/2015 Accepted: 30/07/2015

\begin{abstract}
Long-term study of the life cycle of the freshwater snail Heleobia parchappii (Mollusca: Cochliopidae) in a lentic environment in Argentina

The gastropod Heleobia parchappii is distributed in lentic and lotic environments in the Pampas region of Argentina and is a host for at least 24 species of digeneans. Because ecoparasitological investigations of snail-digenean associations frequently lack knowledge of the structure and dynamics of the snail host population, the purpose of this study is a long-term analysis of the basic aspects of the $H$. parchappii life cycle as a preliminary step of an environmental parasitology study. Monthly collections were made in Nahuel Rucá Lagoon from August 2010 to February 2013, and a total of 24931 individuals of $H$. parchappii were measured and size-frequency distributions were constructed. The von Bertalanffy growth equation and the von Bertalanffy equation with seasonal oscillation growth equations were fit to shell length data. The size-frequency distributions of $H$. parchappii fit a polymodal distribution, and 14 age classes were identified. The breeding periods of $H$. parchappii in 2011 were in summer (February and March), autumn (June) and spring (October). However, in 2012 the periods of recruitment were in autumn (May), winter (July) and spring (October). The von Bertalanffy models best fit the data, and the likelihood ratio test comparison showed significant differences in the estimated parameters between cohorts. This is the first study in which three cohorts of $H$. parchappii were followed from recruitment until death, and a life cycle of approximately 20.33 months was estimated. The observed differences in the recruitment periods and growth parameters could be a strategy by the snail to prevent the negative effects on reproductive success caused by digeneans. We suggest that long-term studies that include a larger number of environmental and biological factors are needed to fully understand the dynamics of the recruitment and growth of juveniles of this species across its distribution range.
\end{abstract}

Key words: Life cycle, shell size, von Bertalanffy growth model.

\section{RESUMEN}

Estudio a largo plazo del ciclo de vida de Heleobia parchappii (Mollusco: cochliopidae) en un ambiente léntico de la República Argentina

El gasterópodo Heleobia parchappii se distribuye en ambientes lénticos y lóticos de la región pampeana de Argentina y es utilizado como hospedador por, al menos, 24 especies de digeneos. Dado que los estudios parasitológicos sobre las asociaciones molusco-digeneo carecen, con frecuencia, del conocimiento previo acerca de la estructura y la dinámica poblacional del hospedador molusco, el propósito de este trabajo es analizar, mediante un estudio a largo plazo, los aspectos básicos del ciclo de vida de $\mathrm{H}$. parchappii, como paso preliminar a la realización de un estudio parasitológico integral. A tal fin, se realizaron capturas mensuales en la Laguna Nahuel Rucá desde agosto del 2010 hasta febrero del 2013. Durante este período se midieron 24931 individuos de $\mathrm{H}$. parchappii, se construyó la distribución de frecuencia de tallas y se analizó si el crecimiento de $\mathrm{H}$. parchappii se ajustaba a los modelos de crecimiento con y sin oscilaciones estacionales de von Bertalanffy. Las distribuciones de frecuencia de tallas se ajustaron a una distribución polimodal y pudieron identificarse 14 clases de edad. El período de reclutamiento de $\mathrm{H}$. parchappii presentó diferencia entre los años estudiados, en el año 2011 el reclutamiento ocurrió en verano (febrero y marzo), en otoño (junio) y en primavera (octubre). Mientras que, en el año 2012 los períodos de reclutamiento fueron en otoño (mayo), en invierno (julio) y en primavera (octubre). El modelo de crecimiento 
de von Bertalanffy fue el que mejor se ajustó a los datos y se observaron diferencias significativas de los parámetros de crecimiento, utilizados por el modelo, entre las cohortes estudiadas. Este es el primer estudio en el que tres cohortes de $\mathrm{H}$. parchappii fueron seguidas desde su reclutamiento hasta su muerte y, por lo tanto, fue posible establecer un ciclo de vida de aproximadamente 20.33 meses. Las diferencias observadas en los períodos de reclutamiento y los parámetros de crecimiento podrían ser resultado de una estrategia del caracol tendiente a evitar los efectos negativos, causados por los digeneos, sobre su éxito reproductivo. Finalmente, se sugiere la necesidad de realizar estudios a largo plazo, que incluyan un mayor número de factores ambientales y biológicos, para comprender plenamente la dinámica de reclutamiento y crecimiento de los juveniles de esta especie a lo largo de su rango de distribución.

Palabras claves: Ciclo de vida, tamaño de la conchilla, modelo de crecimiento de von Bertalanffy.

\section{INTRODUCTION}

Species of the genus Heleobia Stimpson, 1865 inhabit environments with very different salinities, exhibit an integrated diet of many organisms and are important intermediate hosts for some groups of parasites (De Francesco \& Isla, 2004a; Rodrigues \& Bemvenuti, 2011; Alda \& Martorelli, 2014; Merlo et al., 2014; Magnone et al., 2015). However, current knowledge about their biology is not as complete as is desirable. For example, of the 16 species belonging to this genus reported in Argentina (Rumi et al., 2008), only 5 life cycles have been elucidated. Heleobia piscium (d'Orbigny, 1835) and Heleobia conexa presented an annual life cycle (12 months) with a single reproductive period during the summer or spring, respectively (De Francesco \& Isla, 2004a; Martin, 2008). The life cycle of Heleobia australis (d'Orbigny, 1835) varied according to the study site, with a duration between 12 and 30 months and one or two periods of recruitment (summer or spring and summer) (De Francesco \& Isla, 2004b; Carcedo \& Fiori, 2012). In contrast, Heleobia hatcheri (Pilsbry, 1911) is the only species in Argentina and South America with parthenogenetic reproduction (Martín, 2002).

Finally, Heleobia parchappii is the fifth species for which a life cycle is known. This species is widely distributed in lentic and lotic environments in the Pampas region of Argentina and can develop and maintain stable populations in brackish waters with salinities averaging between $17 \%$ and $23 \%$ (Gaillard \& Castellanos, 1976; Castellanos \& Landoni, 1995; De Francesco \& Isla, 2004a). Its life cycle was studied in the lower Colorado River Valley (province of Buenos Aires) and in the Mar Chiquita coastal lagoon area. At both sites, the period of juvenile recruitment occurs from spring to autumn, suggesting an annual life cycle (Cazzaniga, 1981; De Francesco \& Isla, 2004a). Additionally, $H$. parchappii is used as a host by at least 24 species of digeneans (Merlo, 2014; Merlo et al., 2014).

The complex life cycles of digeneans include different larval stages that parasitize molluscs (first intermediate hosts), invertebrates and vertebrates (second intermediate hosts) and finally mature as adults in definitive vertebrate hosts. For this reason, digeneans can be considered as potential bioindicators of environmental conditions. However, the use of larval digeneans in snail hosts as biological indicators requires certain conditions that must be present in the environment under study: i) a diverse and abundant fauna of definitive and intermediate hosts, ii) a community of at least 3 species of larval digeneans in the selected mollusc and iii) preferably previous work including descriptions of larval digeneans in the area (Huspeni et al., 2005). In addition to these requirements, investigation of the temporal variations in digenean prevalence ( $\%$ of parasitized hosts) requires knowledge of the life history patterns of the snail host population because seasonal changes in the digenean prevalence in these hosts can be related to seasonal changes in the age structure of the host population, host recruitment, and host mortality (Rohde, 1981; Fernandez \& Esch, 1991; Snyder \& Esch, 1993; Yoder \& Coggins, 1998). Because ecoparasitological investigations 
of snail-digenean associations frequently lack knowledge of the structure and dynamics of the snail host population, this long-term study aims to analyse in more detail the basic aspects of the $H$. parchappii life cycle as a preliminary step of a parasitological study.

\section{MATERIALS AND METHODS}

\section{Area of study}

The Nahuel Rucá Lagoon $\left(37^{\circ} 37^{\prime} \mathrm{S}, 5^{\circ} 25^{\prime} \mathrm{W}\right)$, located SE of the province of Buenos Aires (Argentina), has an area of 245 ha and a mean depth of $0.14 \pm 0.16 \mathrm{~m}$ (Federman, 2003). Its vegetation is characterized by the presence of Schoenoplectus californicus at its margins, making these environments the main breeding and resting areas of a large number of bird species (Ferrero, 2001; Josens, 2011). Previous investigations in this lagoon include several studies related to vegetation (Stutz, 2000; Isacch, 2001; Federman, 2003), contamination in sediments, macrophytes and fish (Chiodi, 2005; Ondarza, 2005) and birds (Ferrero, 2001; Josens, 2011).

\section{Sampling procedures}

This study was undertaken during a 31-month period from August 2010 to February 2013. Specimens of $H$. parchappii located among the submerged vegetation and on the substratum were collected monthly with the aid of sieves $(0.5 \mathrm{~mm})$ and placed into plastic cups filled with water from the lagoon for transportation. The water temperature and salinity were measured monthly using a Digital Multi-Thermometer (range $-50{ }^{\circ} \mathrm{C}$ to $150{ }^{\circ} \mathrm{C}$ ) and a Portable Refractometer FG- 211 Salinity/ATC 0\%o 100\%o (CHINCAN, Beijing China), respectively. In the laboratory, snails were placed in $1 \mathrm{~L}$ containers with filtered water from the lagoon with an aerator. Subsequently, snails were measured under a stereoscopic microscope with an ocular micrometre (precision $0.05 \mathrm{~mm}$ ). Total shell length (the distance from the apex to the anterior margin of the aperture) was used as an estimate of size.
Table 1. Heleobia parchappii. Maximum likelihood parameter estimates corresponding to the von Bertalanffy function models. Estimación de los parámetros de crecimiento de las funciones de von Bertalanffy.

\begin{tabular}{lcrrr}
\hline Model & Parameters & \multicolumn{3}{c}{ Cohort } \\
\cline { 3 - 5 } & & 6 & 7 & 8 \\
\hline \multirow{3}{*}{ von Bertalanffy } & $L_{\infty}$ & 8.24 & 9.55 & 8.68 \\
& $K$ & 1.43 & 0.74 & 0.81 \\
& $t_{0}$ & -0.37 & -0.58 & -0.42 \\
\hline \multirow{2}{*}{ von Bertalanffy } & $L_{\infty}$ & 8.59 & 9.45 & 8.73 \\
Seasonal oscillations & $K$ & 1.17 & 0.74 & 0.83 \\
& $t_{0}$ & -0.49 & -0.55 & -0.35 \\
& $C$ & 0.56 & 0.17 & 0.24 \\
& $t_{s}$ & 0.15 & 2.93 & 1.83 \\
\hline
\end{tabular}

\section{Data analysis}

To recognize dominant size groups, the data obtained were used to construct size-frequency distributions that were analysed using the Bhattacharya method (FiSAT II software), which separates normal distributions in a mixture of distributions in length-frequency data. This method allows estimation of the mean lengths and standard deviations for the identified age groups (Gayanilo et al., 1995), and these results were used to separate cohorts. To confirm each component of the normal distribution from the modal progression analysis, we used the NORMSEP method also available in the FISAT II software (Pauly \& Caddy, 1985).

The von Bertalanffy growth equation and the von Bertalanffy equation with seasonal oscillations fit to the shell length data obtained from cohorts 6,7 and 8 , which were used because they were followed from their recruitment until death. These growth models were expressed as $L_{t}=L_{\infty}\left(1-\exp ^{-K\left[\left(t-t_{0}\right)\right.}\right)$ and $L_{t}=$ $L_{\infty}\left(1-\exp ^{-K\left[\left(t-t_{0}\right)+C \sin \left(2 \pi\left(t-t_{s}\right)\right) / 2 \pi-C \sin \left(2 \pi\left(t_{0}-t_{s}\right)\right) / 2 \pi\right]}\right)$. $L_{t}$ is the predicted length at age $t ; L_{\infty}$ is the asymptotic length, $K$ is the growth constant of dimension time $^{-1}$ (year $^{-1}$ in most seasonally oscillating growth curves) expressing the rate at which $L_{\infty}$ is approached; $t_{0}$ is the theoretical 'age' of the molluscs at length zero; $C$ expresses the relative amplitude of the seasonal oscillation, and $t_{s}$ is the starting point of the 

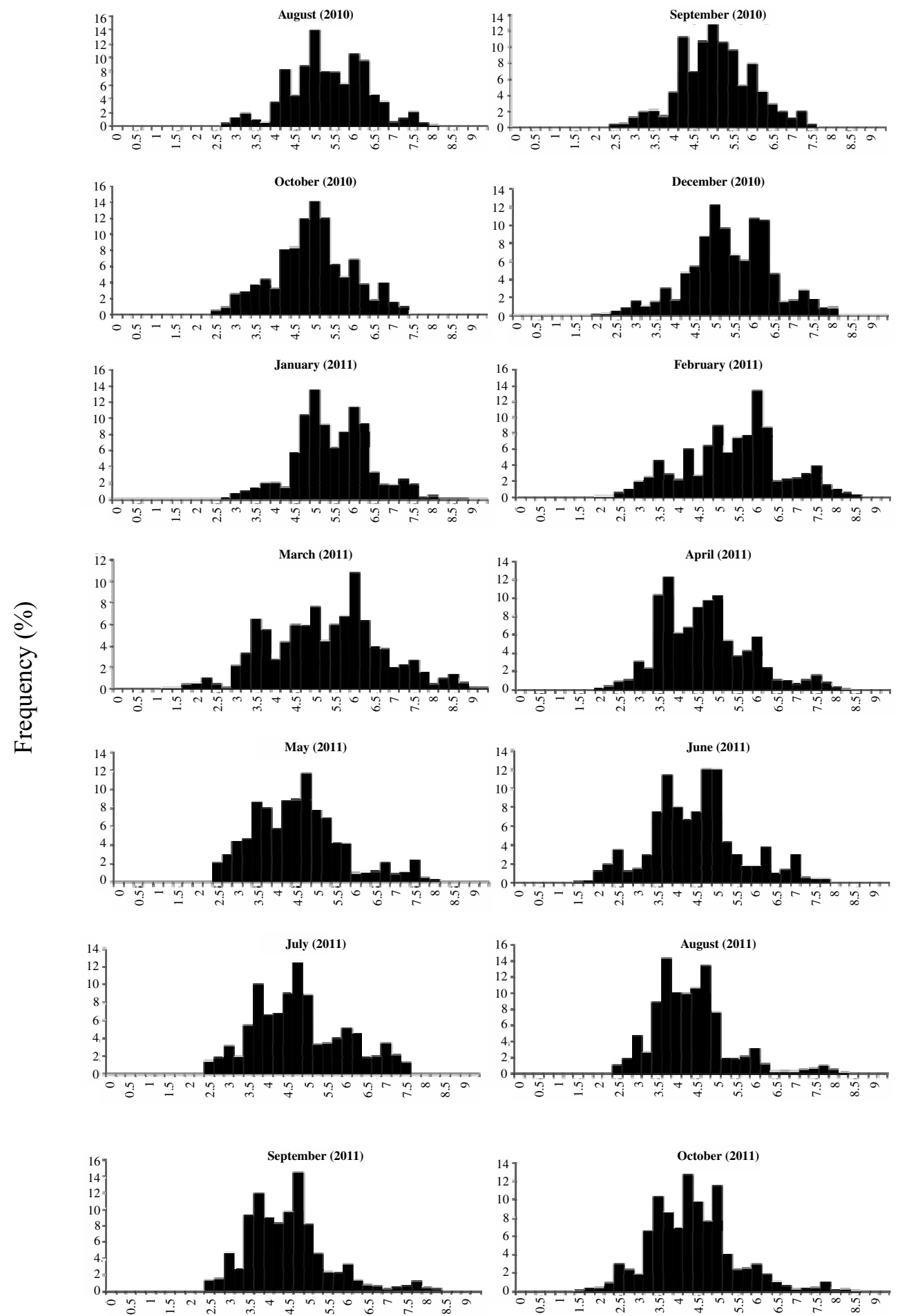

Shell length (mm)

Figure 1. Size-frequency distributions histograms of Heleobia parchappii at Nahuel Rucá Lagoon from August 2010 to February 2013. Histogramas de distribución de frecuencia de tallas de Heleobia parchappii en la Laguna Nahuel Rucá desde agosto de 2010 a febrero de 2013. 

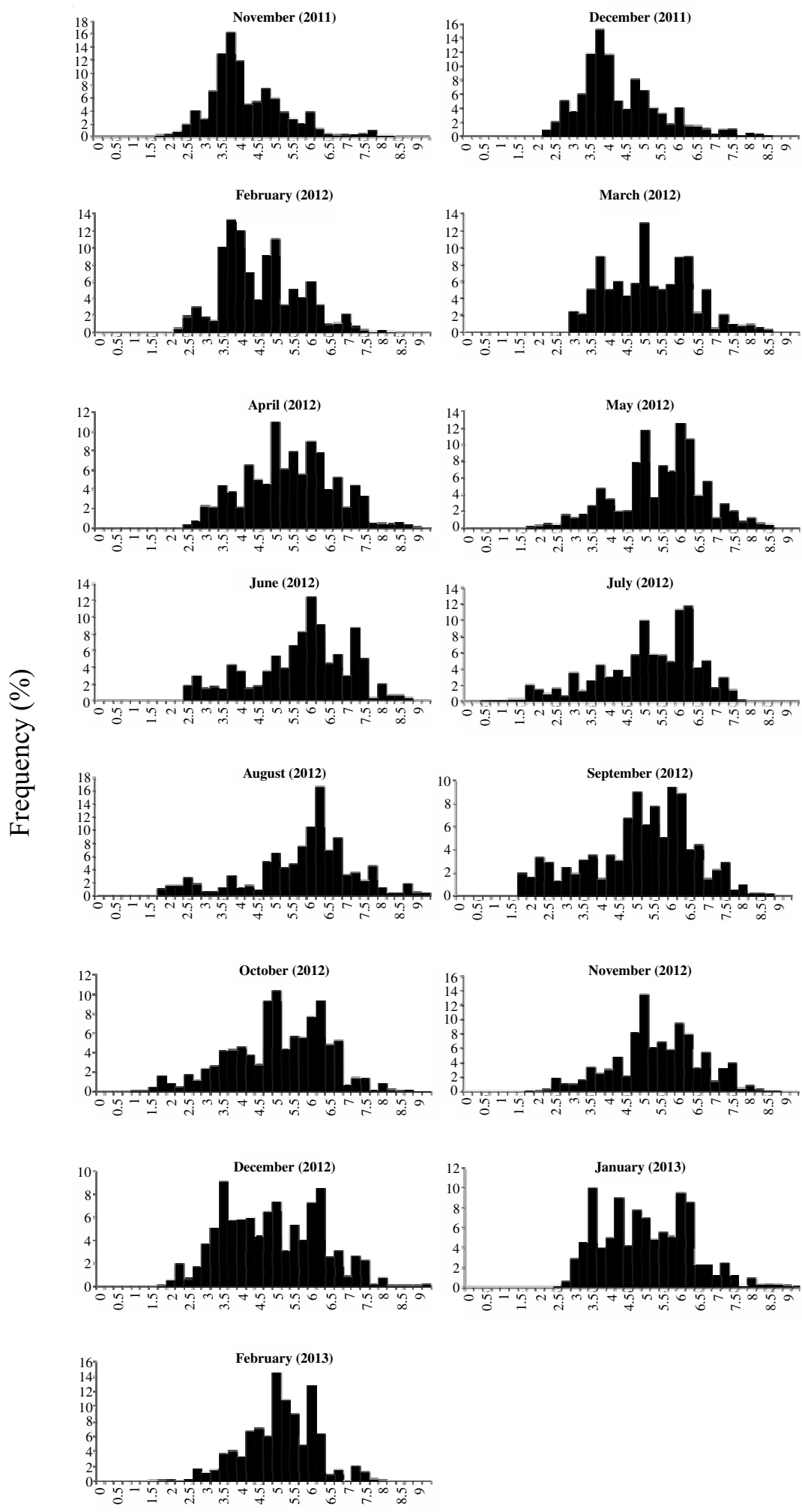

Shell length (mm) 
Table 2. Heleobia parchappii. Results of the selection model that best fits the curve of growth (Fig. 2) for cohorts 6,7 and 8 . Number of parameters ( $\mathrm{n}^{\mathrm{o}}$ par), Akaike's information criterion (AIC), Akaike differences ( $\triangle \mathrm{AIC}$ ), normalized weights of AIC (w\%). Evaluación de los modelos de crecimiento de von Bertalanffy y von Bertalanffy con oscilaciones estacionales, para las cohortes 6 , 7 y 8. Número de parámetros ( $n^{\circ}$ par), criterio de información de Akaike (AIC), las diferencias de Akaike ( $\left.\triangle A I C\right)$, pesos normalizados de $\operatorname{AIC}(w \%)$.

\begin{tabular}{|c|c|c|c|c|c|}
\hline Cohort & Model & $\mathrm{n}^{\mathrm{o}}$ par & AIC & $\Delta \mathrm{AIC}$ & $\mathrm{w}(\%)$ \\
\hline \multirow{2}{*}{6} & von Bertalanffy & 3 & -55.80 & 0 & 49.20 \\
\hline & von Bertalanffy seasonal oscillations & 5 & -53.77 & 2.03 & 17.81 \\
\hline \multirow{2}{*}{7} & von Bertalanffy & 3 & -71.13 & 0 & 32.79 \\
\hline & von Bertalanffy seasonal oscillations & 5 & -68.08 & 3.05 & 7.14 \\
\hline \multirow[b]{2}{*}{8} & von Bertalanffy & 3 & -61.48 & 0 & 40.34 \\
\hline & von Bertalanffy seasonal oscillations & 5 & -59.00 & 2.48 & 11.68 \\
\hline
\end{tabular}

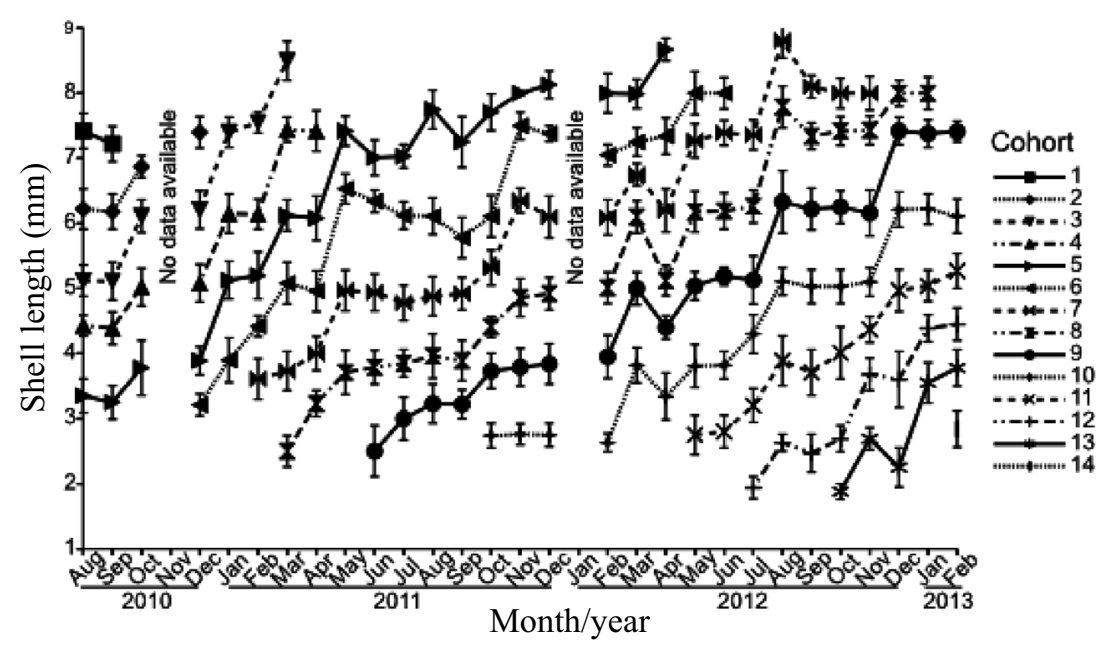

Figure 2. Growth curves of Heleobia parchappii estimated by cohort separation from August 2010 to February 2013. Estimated averages ( \pm standard deviation) of the normal curves fit to the size-frequency histograms (Figure 1) are shown. Curva de crecimiento de cada cohorte de Heleobia parchappii desde agosto de 2010 a febrero de 2013. Tallas medias ( \pm desviación estándar) estimadas a partir de los histogramas de distribución de frecuencia de tallas de la Figura 1.

oscillation (von Bertalanffy, 1938; Pauly \& Gaschütz, 1979). The Akaike information criterion (AIC; Akaike, 1973) and Akaike's weight (w) (Franklin et al., 2001) were used to assess model performance. Then, in order to evaluate differences in the growth curves from cohorts 6 , 7 and 8, the von Bertalanffy growth parameters were compared using a likelihood ratio test (Kimura, 1980; Cerrato, 1990).

The monthly density of $H$. parchappii was calculated as the number of individuals/1 hour of sampling. This method for quantifying density was adopted due to the turbidity of the lagoon, which made it impossible to either view the substratum or collect all of the snails in a given area (Prepelitchi, 2009). The monthly densities were compared using a one-way ANOVA. Tukey tests were performed for post-hoc comparisons (Zar, 2009). Homogeneity of variances and normality were confirmed prior to all analyses with Levene and Shapiro-Wilks, respectively (Zar, 2009).

\section{RESULTS}

A total of 24931 individuals of $H$. parchappii were measured; the maximum shell size recorded was $9.36 \mathrm{~mm}$, while the minimum value was $0.50 \mathrm{~mm}$. Size-frequency distributions of $H$. parchappii fit a polymodal distribution (Fig. 1), and fourteen age classes were identified over the 31 months of study (Fig. 2). Cohorts 6, 7 and 8 were 
followed from the snails' recruitment until their death. Cohort 6 was followed for 18 months, while cohorts 7 and 8 were followed for 21 and 22 months, respectively. The life cycle of $H$. parchappii in Nahuel Rucá Lagoon thus showed an average duration of 20.33 months. The breeding period of $H$. parchappii took place in all seasons of the year, but these seasons differed between the years of study. In 2010, we detected one recruitment period in summer (November or December, no data were available in November). In 2011, we detected recruitment periods in summer (February and March), autumn (June) and spring (October). However, in 2012, the periods of recruitment were autumn (May), winter (July) and spring (October) (Fig. 2).

The parameters of the von Bertalanffy models of cohorts 6,7 and 8 are summarized in Table 1 ; in all cases, the von Bertalanffy model was the one that best fit the data (Table 2). The likelihood ratio test comparison showed significant differences in the estimated parameters between the cohorts. The growth constant $(K)$ of cohort 6 was twice those observed in cohorts 7 and 8 . However, $L_{\infty}$ was similar for the three cohorts (Table 3).
Table 3. Comparison of growth parameters estimated from the von Bertalanffy model by the likelihood ratio test. Comparación mediante la prueba de la razón de verosimilitud de los parámetros estimados del modelo de crecimiento de von Bertalanffy.

\begin{tabular}{lccc}
\hline Cohort & $\mathrm{Ho}_{1}$ & $\mathrm{Ho}_{2}$ & $\mathrm{Ho}_{3}$ \\
& $L_{\infty 1}=L_{\infty 2}$ & $K_{1}=K_{2}$ & $t_{01}=t_{02}$ \\
\hline 6 vs 7 & n.s. & $<0.001$ & $<0.001$ \\
6 vs 8 & n.s. & $<0.001$ & n.s. \\
7 vs 8 & n.s. & n.s. & n.s. \\
\hline
\end{tabular}

Heleobia parchappii densities ranged from $240 \mathrm{ind} . / \mathrm{hr}$ (March, 2012) to $1478 \mathrm{ind} . / \mathrm{hr}$ (October, 2012) and showed fluctuations throughout the months under study $\left(F_{28 ; 116}=14.13\right.$; $p<0.0001)$. Analysing consecutive months revealed differences between June and July (2012) and between September and October (2012) (in both cases $p<0.05$ ). Despite this, the temporal dynamics of the $H$. parchappii densities were relatively constant throughout the study, increasing in spring (October-November) and decreasing towards winter (June-July). Nevertheless, in the winter of 2012 (July), a peak density associated with the reproductive event mentioned previously was observed (Fig. 3).

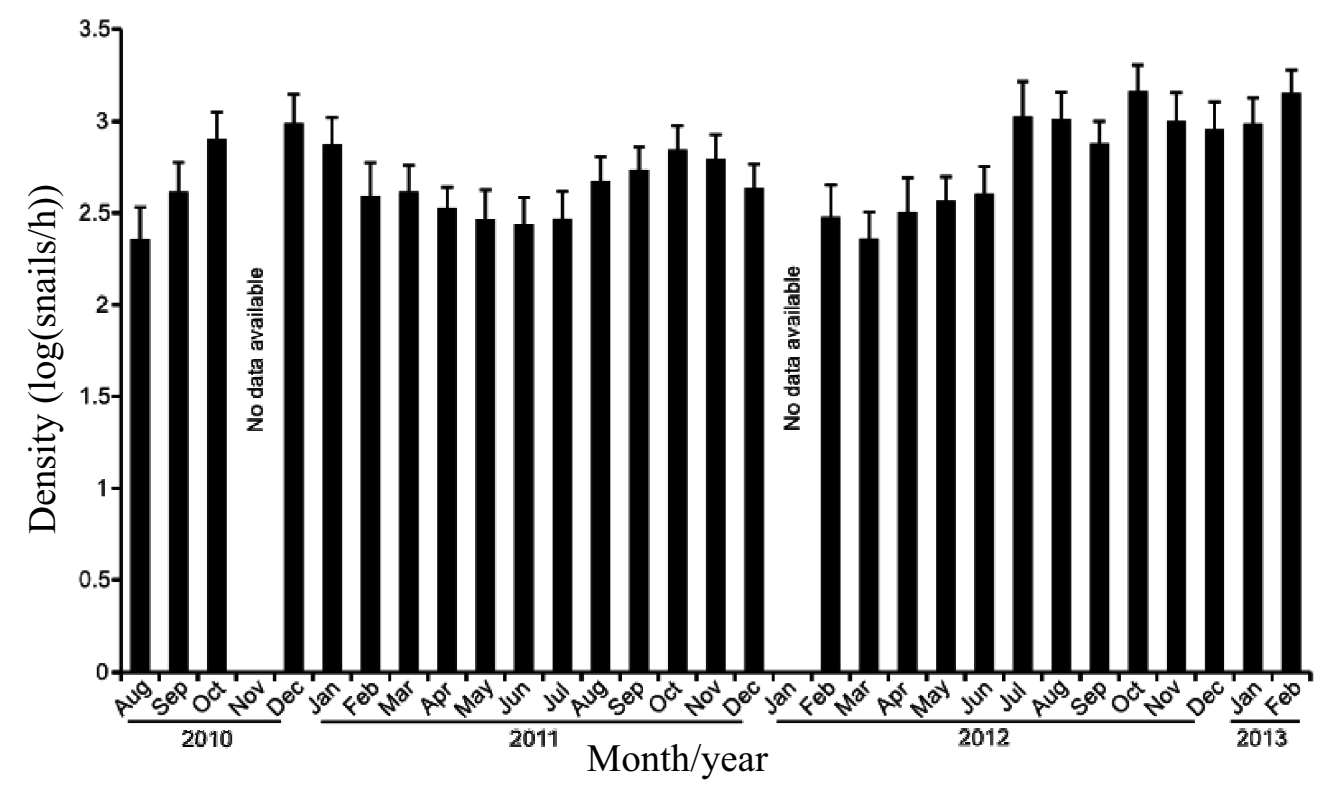

Figure 3. Mean density ( \pm standard deviation) of Heleobia parchappii at Nahuel Rucá Lagoon from August 2010 to February 2013. Densidad media ( \pm desviación estándar) de Heleobia parchappii en la Laguna Nahuel Rucá desde agosto de 2010 a febrero de 2013. 
Regarding the abiotic factors measured in Nahuel Rucá Lagoon, the water temperature ranged from $1.2{ }^{\circ} \mathrm{C}$ (June 2012) to $28.9^{\circ} \mathrm{C}$ (December 2010). Salinity was constant throughout the year, being highest in June and August (2010) $(0.68 \%)$ and lowest in October and November (2010) and in January, March and November (2011) (0.62\% ) (Fig. 4).

\section{DISCUSSION}

This is the first study in which three cohorts of $H$. parchappii were followed from recruitment until death, and a life cycle of approximately 20.33 months was estimated for this species. Our results contrast with those of Cazzaniga (1981) in the lower Colorado River Valley (province of Buenos Aires) and De Francesco \& Islas (2004a) in the Mar Chiquita coastal lagoon. These authors suggested an annual (approximately 12 months) life cycle for $H$. parchappii.

The $H$. parchappii population in Nahuel Rucá exhibits a seasonal cycle of reproductive activity with three main spawning peaks. In 2011 and 2012, two of the three breeding seasons were observed in autumn (June 2011 and May 2012) and in spring (October 2011 and 2012); a similar reproductive pattern was found by Cazzaniga (1981) and De Francesco \& Isla (2004a). The spring peak seems to be more important, based on the higher abundance of snails observed. However, the third reproductive peak varied over the years of studies; in 2011 recruitment of juve- niles occurred during the summer (February and March), while in 2012 recruitment was detected in winter (July). This last winter recruitment was mentioned by Cazzaniga (1981), but not by De Francesco \& Isla (2004a).

Some authors have linked the recruitment of juvenile gastropods with water temperature and salinity (De Francesco, 2002; De Francesco \& Isla, 2004a; Malavé et al., 2012; Yakovis et al., 2013). In this study, the relationship between recruitment and water temperature was partly contradictory. For example, the spring and summer recruitments coincided with water temperatures above $15^{\circ} \mathrm{C}$, and recruitment occurring in the winter of 2012 (July) coincided with an $8{ }^{\circ} \mathrm{C}$ increase of water temperature compared with the previous month (June), reaching up to $10^{\circ} \mathrm{C}$. However, fall recruitments coincided with temperatures of approximately $5^{\circ} \mathrm{C}$. These results contrast with those obtained by De Francesco \& Isla (2004a), which indicated that recruitment periods start when the temperature reaches $20^{\circ} \mathrm{C}$. Furthermore, no relationship was observed between the periods of recruitment and salinity, a result mainly due to the salinity remaining constant throughout the study. From these results, temperature and salinity could not be considered as the only decisive factors affecting the breeding season.

Parasitism is another factor that may affect recruitment and growth in snails (Lefcort et al., 2002; Gilardoni et al., 2012). Digeneans generally reduce reproductive success and can alter the growth rate of their hosts. However, the

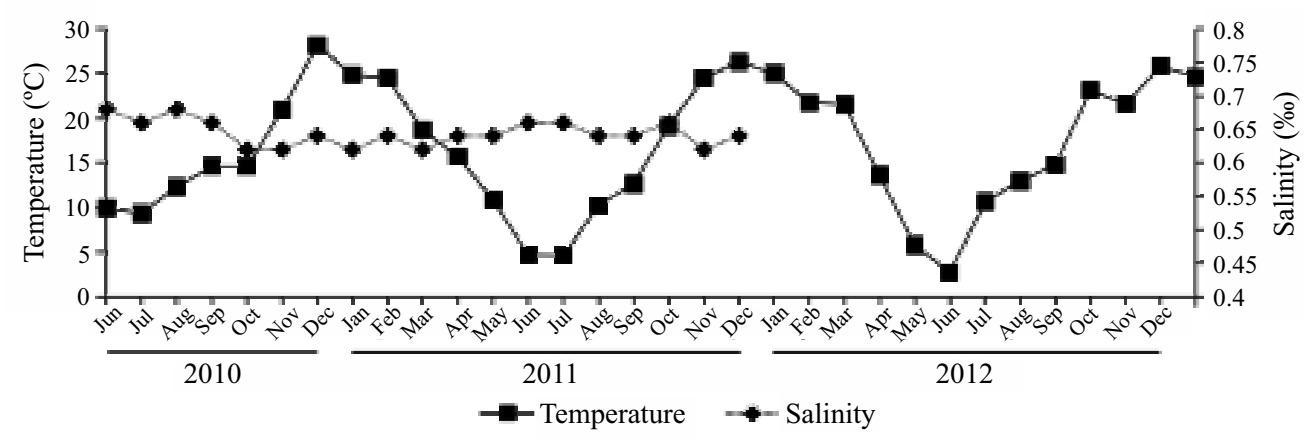

Figure 4. Annual distribution of the water temperature and salinity in Nahuel Rucá Lagoon. Distribución anual de la temperatura y la salinidad del agua en la Laguna Nahuel Rucá. 
molluscs can employ physiological and immunological defence mechanisms to prevent infection (Trail,1980; Minchella, 1985; Gustafson \& Bolek, 2014). One alternative strategy available for the host is to vary individual life history parameters (e.g., reproductive periods, growth rate) to prevent or at least minimize the negative effects of parasitism on reproductive success, with a lower cost in energy (Minchella, 1985). Therefore, the lower growth rates observed in cohorts 7 and 8 could be an adaptation to infection by digeneans because the energy currently used for host body growth becomes available for reproduction. Additionally, Merlo (2014) found 24 species of digeneans parasitizing $H$. parchappii. These parasites showed temporal variations in prevalence; in the warmer months (DecemberMarch) prevalence values were higher than in the colder months (June-September). Overall, previous studies have shown a positive influence of water temperature on the rate of development of the eggs of digeneans and on the time of emergence and lifetime of the miracidia. In addition, a direct relationship exists between the size of the host and the prevalence of infection by digeneans (Kuris, 1979; Vanoverschelde, 1982; Flores et al., 2010). Individuals of $H$. parchappii recruited during winter (June (2011), July and August (2012)) would have minor probabilities of being infected by digeneans and would therefore have greater possibilities of development and higher reproductive success. Thus, reproductive periods of $H$. parchappii in the colder months of the year and different growth rates between the cohorts could be seen as a strategy to increase their reproductive success. As mentioned above, the use of larval digeneans as tools to study biotic communities requires knowledge of the population dynamics of their first intermediate host. Hence, recruitment periods throughout the year and the relatively short life cycle of $H$. parchappii favours the availability of individuals as potential hosts and makes possible a quick restructuring snail-digenean system. This restructuring could allow inferences about environmental changes over short periods of time, including disturbances due to human activity and fluctuations in the diversity and abundance of vertebrate hosts (Merlo \& Etchegoin, 2011; Etchegoin et al., 2012).

Taking into account the different results obtained in the studies of the reproductive dynamics of $H$. parchappii in different sites of its distribution in Argentina, we suggest that long-term studies that include a larger number of environmental and biological factors (e.g., the incidence of ultraviolet radiation, periods of rainfall, pollution and food availability) are needed to fully understand the dynamics of the recruitment and growth of juveniles of this species throughout its range.

\section{ACKNOWLEDGEMENTS}

We thank Mr. Pedro Urrutia for allowing us to work in Nahuel Rucá Lagoon. M. J. Merlo, M. Parietti and J. A. Etchegoin are members of Consejo Nacional de Investigaciones Científicas y Técnicas (CONICET). This work was supported by Consejo Nacional de Investigaciones Científicas y Técnicas (CONICET) (J.A.E. PIP 112-201101-00113) and Universidad Nacional de Mar del Plata (J.A.E., grant number EXA 583/12 15/E531).

\section{REFERENCES}

AKAIKE, H. 1973. Information theory and an extension of the maximum likelihood principle. In: Second International Symposium on Information Theory. B.N. Petrov \& F. Csaki (eds): 267-81. Akademiai Kiado, Budapest.

ALDA, P. \& S. R. MARTORELLI. 2014. Larval trematodes infecting the South-American intertidal mud snail Heleobia australis (Rissooidea: Cochliopidae). Acta Parasitologica, 59: 50-67.

CARCEDO, M. C. \& S. M. FIORI. 2012. Long-term study of the life cycle and growth of Heleobia australis (Caenogastropoda, Cochliopidae) in the Bahía Blanca estuary, Argentina. Ciencias Marinas, 38: 589-597.

CASTELLANOS, Z. J. A. \& N.A. LANDONI. 1995. Mollusca Pellecypoda y Gasteropoda. In: Ecosistemas de aguas continentales III, Metodologías para su estudio. E.C. Lopretto \& G. Tell (eds): 759-802. Ediciones Sur, La Plata. 
CAZZANIGA, N. J. 1981. Estudios bio-ecológicos de gasterópodos dulceacuícolas relacionados con la invasión de canales por malezas acuáticas. $\mathrm{Ph}$. D. Thesis. Universidad Nacional de La Plata, Argentina.

CERRATO, R. M. 1990. Interpretable statistical test for growth comparison using parameters in the von Bertalanffy equation. Canadian Journal of Fisheries and Aquatic Sciences, 47: 1416-1426.

CHIODI, L. 2005. Dinámica de metales pesados en sedimentos, hidrófitas y peces de la laguna $\mathrm{Na}$ huel-Rucá (Cuenca de la laguna costera Mar Chiquita, Prov. de Bs. As.). Thesis. Universidad Nacional de Mar del Plata, Argentina.

DE FRANCESCO, C. G. 2002. Significado paleobiológico y paleoambiental de las concentraciones holocenas de Heleobias (Gastropoda) presentes en el sudeste de las Provincia de Buenos Aires. Ph. D. Thesis. Universidad Nacional de Mar del Plata, Argentina.

DE FRANCESCO, C. G. \& F. I. ISLA. 2004a. Reproductive period and growth rate of the freshwater snail Heleobia parchappii (d'Orbigny, 1835) (Gastropoda: Rissooidea) in a shallow brackish habitat (Buenos Aires Province, Argentina). Malacologia, 45: 443-450.

DE FRANCESCO, C. G. \& F. I. ISLA. 2004b. The life cycle and growth of Heleobia australis (D'Orbigny, 1835) and H. conexa (Gaillard, 1974)(Gastropoda: Rissooidea) in Mar Chiquita coastal lagoon (Argentina). Journal of Molluscan Studies, 70: 173-178.

ETCHEGOIN, J. A., M. J. MERLO \& M. PARIETTI. 2012. The role of the invasive polychaete Ficopomatus enigmaticus (Fauvel, 1923) (Serpulidae) as facilitator of parasite transmission in Mar Chiquita coastal lagoon (Buenos Aires, Argentina). Parasitology, 139: 1506-1512.

FEDERMAN, M. 2003. Mapeo y caracterización de la comunidad de macrófitas en tres lagos someros del Sudeste Bonaerense. Thesis. Universidad Nacional de Mar del Plata, Argentina.

FERNÁNDEZ, J. \& G. W. ESCH. 1991. Effect of parasitism on the growth rate of the pulmonate snail Helisoma anceps. Journal of Parasitology, 77: 937-944.

FERRERO,L. 2001. Avifauna de Mar Chiquita (Síntesis del trabajo de Mariano M. Martínez). In: Reserva de Biosfera Mar Chiquita: Características físicas, biológicas y ecológicas. O.O Iribarne (ed): 227-250. Editorial Martín. Mar del Plata.
FLORES, V. R., L. G. SEMENAS \& A. A. VELEIZÁN. 2010. Larval digenean community parasitizing the freshwater snail, Biomphalaria peregrina (Pulmonata: Planorbidae), from a temporary pond in Patagonia, Argentina. Journal of Parasitology, 96: 652-656.

FRANKLIN, A. B., T. M. SHENK, D. R. ANDERSON \& K. P. BURNHAM. 2001. Statistical model selection: an alternative to null hypothesis testing. In: Modeling in Natural Resource Management: Development, Interpretation, and Application. T. M. Shenk \& A. B Franklin (eds): 75-90. Island Press, Washington, DC.

GAILLARD, M. C. \& Z. A. CASTELLANOS. 1976. Mollusca Gastropoda Hydrobiidae. In: Fauna de agua dulce de la República Argentina. R. A. Ringuelet (ed): 1-40. FECIC, Buenos Aires.

GAYANILO, F. C., P. SPARRE \& D. PAULY. 1995. The FAO-ICLARM Stocks Assessment Tools (FiSAT). User's Guide. FAO Computerized Information Series (Fisheries) 8.

GILARDONI, C., C. ITUARTE \& F. CREMONTE. 2012. Castrating effects of trematode larvae on the reproductive success of a highly parasitized population of Crepipatella dilatata (Caenogastropoda) in Argentina. Marine Biology, 159: 2259-2267.

GUSTAFSON, K. D \& M. G. BOLEK. 2014. Tradeoff between establishing an infection and killing the host: response of snails (Physa acuta) to a gradient of trematode (Halipegus eccentricus) exposures. Journal of Parasitology. In-Press.

HUSPENI, T. C., R. F. HECHINGER \& K. D. LAFFERTY. 2005. Trematode parasites as estuarine indicators: opportunities, applications and comparisons with conventional community approaches. In: Estuarine Indicators. S. A. Bortone (ed): $297-$ 314. CRC Press, Boca Raton.

ISACCH, J. P. 2001. Mapa de la vegetación del área de la Reserva Mar Chiquita y áreas circundantes. In: Reserva de Biosfera Mar Chiquita: Características físicas, biológicas y ecológicas. O. O Iribarne (de): 79-82. Editorial Martín. Mar del Plata.

JOSENS, M. L. 2011. Rol de las Comunidades de Aves Acuáticas en Lagunas Continentales del Sudeste Bonaerense: Un estudio de su Estructura, Impacto y Estacionalidad. $\mathrm{Ph}$. D. Thesis. Universidad Nacional de Mar del Plata, Argentina.

KIMURA, D. K. 1980. Likelihood methods for the estimation the von Bertalanffy growth curve. Fishery Bulletin, 77: 765-776. 
KURIS, A. M. 1979. Echinostoma liei miracidia and Biomphalaria glabrata snails: effect of egg age, habitat heterogeneity, water quality and volume on infectivity. International Journal for Parasitology, 10: 21-25.

LEFCORT, H., M. Q. AGUON, K. A. BOND, K. R. CHAPMAN, R. CHAQUETTE, J. CLARK, P. KORNACHUK, B. Z. LANG \& J. C. MARTIN. 2002. Indirect effects of heavy metals on parasites may cause shifts in snail species compositions. Archives of Environmental Contamination and Toxicology, 43: 34-41.

MAGNONE, L., M. BESSONART, J. GADEA \& M. SALHI. 2015. Trophic relationships in an estuarine environment: A quantitative fatty acid analysis signature approach. Estuarine, Coastal and Shelf Science. In press.

MALAVÉ, C., L. FREITES, C. LODEIROS, J. MENDOZA, L. TROCCOLI \& A.W. DALE. 2012. Annual recruitment, predation rates and biocontrol of Linatella caudata (Mollusca: Gastropoda) in suspended enclosure culture of the pearl oyster Pinctada imbricata. Aquaculture, 354: 75-83.

MARTÍN, P. R. 2002. Evidence for parthenogenesis and natural imposex in the Patagonian freshwater snail Heleobia hatcheri (Gastropoda: Hydrobiidae). Journal of Molluscan Studies, 68: 291-295.

MARTIN, S. M. 2008. Individual growth of Heleobia piscium in natural populations (Gastropoda: Cochliopidae) from the multiple use natural Reserve Isla Martín García, Buenos Aires, Argentina. Brazilian Journal of Biology, 68: 617-621.

MINCHELLA, D. J. 1985. Host life-history variation in response to parasitism. Parasitology, 90: 205216.

MERLO, M. J. 2014. Ecología de las comunidades de digeneos larvales en hospedadores moluscos del género Heleobia Stimpson, 1865 (Gastropoda: Rissooidea). Ph. D. Thesis. Universidad Nacional de Mar del Plata, Argentina.

MERLO, M. J. \& J. A. ETCHEGOIN. 2011. Testing temporal stability of the larval digenean community in Heleobia conexa (Mollusca: Cochliopidae) and its possible use as an indicator of environmental fluctuations. Parasitology, 138: 249-256.

MERLO, M. J., M. PARIETTI \& J. A. ETCHEGOIN. 2014. Digeneos larvales de Heleobia parchappii y de Heleobia australis en ambientes dulceacuícolas y estuariales de la provincia de Buenos Aires (Argentina). Revista Argentina de Parasitología, 2: 14-21.
ONDARZA, P. 2005. Dinámica de plaguicidas organoclorados en la laguna Nahuel Rucá, cuenca de la laguna costera Mar Chiquita. Sedimentos, macrófitas y peces como potenciales remediadores. Thesis. Universidad Nacional de Mar del Plata, Argentina.

PAULY,D. \& G. GASCHÜTZ. 1979. A simple method for fitting oscillating length growth data, with a program for pocket calculator. International Council for the Exploration of the Seas, Council Meeting Demersal Fish Committee, 6: 24-26.

PAULY,D. \& J. F. CADDY. 1985. A modification of Bhattacharya's method for analysis of mixtures of normal distributions. FAO Fisheries Circular, 781:1-16.

PREPELITCHI, L. 2009. Ecoepidemiología de Fasciola hepatica (Trematoda, Digenea) en el norte de la Provincia de Corrientes destacando aspectos ecológicos de Lymnaea columella (Pulmonata, Lymnaeidae) y su rol como hospedador intermediario. Ph. D. Thesis. Universidad Nacional de Buenos Aires, Argentina.

RODRIGUES, F. L. \& M. A. BEMVENUTI. 2011. Diet and feeding strategy of the silverside Odontesthes bonariensis (Valenciennes 1835) (Atheriniformes: Atherinopsidae) from the Mirim Lagoon, Rio Grande do Sul, Brazil. Pan-American Journal of Aquatic Sciences, 6: 161-169.

ROHDE, K. 1981. Population dynamics of two snail species, Planaxis sulcatus and Cerithium moniliferum, and their trematode species at Heron Island, Great Barrier Reef. Oecologia, 49: 344-352.

RUMI, A., D. E. GUTIÉRREZ GREGORIC, V. NÚNEZ \& G. A. DARRIGRAN. 2008. Malacología Latinoamericana. Moluscos de agua dulce de Argentina. Revista de Biología Tropical, 56: 77-111.

SNYDER, S. D. \& G. W. ESCH. 1993. Trematode community structure in the pulmonate snail Physa gyrina. Journal of Parasitology, 79: 205-215.

STUTZ, S. B. 2000. Historia de la vegetación del litoral bonaerense durante el último ciclo transgresivo-regresivo del Holoceno. Ph. D. Thesis. Universidad Nacional de Mar del Plata, Argentina.

TRAIL, D. R. S. 1980. Behavioral interactions between parasites and hosts: host suicide and the evolution of complex life cycles. American Naturalist, 116: 77-91.

VANOVERSCHELDE, R. 1982. Studies on the life cycle of Himasthla militaris (Trematoda: Echinostomatidae): influence of temperature and salinity 
on the life-span of the miracidium and the infection of the first intermediate host Hydrobia ventrosa. Parasitology, 84: 131-135.

VON BERTALANFFY, L. 1938. A quantitative theory of organic growth. Human Biology, 10: 181-213. YAKOVIS, E. L., A.V. ARTEMIEVA, M. V. FOKIN, M. A. VARFOLOMEEVA \& N. N. SHUNATOVA. 2013. Synchronous annual recruitment variation in barnacles and ascidians in the White Sea shallow subtidal 1999-2010. Hydrobiologia, 706: 1-11.

YODER, H. R. \& J. R. COGGINS. 1998. Larval trematode assemblages in the snail Lymnaea stagnalis from southeastern Wisconsin. The Journal of parasitology, 84: 259-268.

ZAR, J. H. 2009. Biostatistical analysis. Pearson Education, Inc. New Jersey. U.S.A. 